\title{
Development of a new disinfectant with very strong anti-influenza viral activity: a preliminary report
}

\author{
Hiroki Takakuwa $\cdot$ Toshiyuki Maruoka $\cdot$ Tadayo Hata $\cdot$ \\ Masaaki Miyazawa $\cdot$ Tomoyo Hata $\cdot$ Hitoshi Toshimori · \\ Koichi Otsuki
}

Received: 12 November 2008 / Accepted: 9 September 2009/Published online: 6 October 2009

(C) The Japanese Society for Hygiene 2009

\begin{abstract}
Objectives We evaluated the effectiveness and safety of a disinfectant newly developed by our laboratories for use against influenza viruses.

Methods The effectiveness of our new disinfectant against avian, swine and human influenza viruses was tested in ovo. The acute toxicity of this disinfectant to two different cultured cell lines was investigated.

Results This new disinfectant showed very strong antiinfluenza viral activity in the in ovo tests. All of the influenza viruses tested were inactivated very quickly. Following exposure to the disinfectant, the infectivity of all viral strains tested had been eliminated within $\leq 10 \mathrm{~min}$. The infectant showed a weak acute toxicity in vitro.

Conclusion This new disinfectant is expected to be useful for preventing viral infection during a new influenza pandemic.
\end{abstract}

H. Takakuwa $\cdot$ K. Otsuki $(\square)$

Avian Influenza Research Centre,

Kyoto Sangyo University,

Motoyama Kamigamo, Kita-ku,

Kyoto 603-8555, Japan

e-mail: k3666@cc.kyoto-su.ac.jp

T. Maruoka - Tadayo Hata - Tomoyo Hata $\cdot$ H. Toshimori Bacteria Research Center,

Shionomiya Hot Spring Hospital-Zaidanhojin Seikenkai,

Tondabayashi, Osaka, Japan

M. Miyazawa

Department of Immunology,

Kinki University School of Medicine,

Osakasayama, Osaka, Japan

K. Otsuki

Avian Zoonoses Research Centre,

Faculty of Agriculture, Tottori University, Tottori, Japan
Keywords Avian influenza virus · Human influenza virus $\cdot$ New disinfectant $\cdot$ Strong activity .

Swine influenza virus

\section{Introduction}

Outbreaks of highly pathogenic avian influenza and other emerging and re-emerging diseases have caused serious economical and social disturbances worldwide [1-4]. Although the pandemic H1N1 subtype influenza virus has rapidly spread throughout the world since the end of April 2009 , the production of a new influenza vaccine is still insufficient. However, the preparation of large amounts of medicine effective against influenza was also difficult prior to the occurrence of this latest pandemic. Therefore, there is a need to develop possible control methods, such as an easily obtained, effective disinfectant to prevent the virus from spreading. Our laboratories have succeeded in developing a new disinfectant which consists mainly of an iron ion. Tests have demonstrated that this disinfectant in very efficient in rapidly inactivating bacteria and influenza viruses.

\section{Materials and methods}

Experiment 1

The new disinfectant was prepared as follows. First, solution A was made by dissolving $0.96 \mathrm{~g} \mathrm{FeCl}_{3} 6 \mathrm{H}_{2} \mathrm{O}$ in $200 \mathrm{ml}$ distilled water. Next, solution $\mathrm{B}$ was prepared by dissolving $1 \mathrm{~g}$ L-cysteine, $0.1 \mathrm{~g}$ ascorbic acid, $0.05 \mathrm{~g}$ potassium sorbate and $0.1 \mathrm{~g}$ sodium lauryl sulfate in $800 \mathrm{ml}$ distilled water. Solutions A $(200 \mathrm{ml})$ and B $(800 \mathrm{ml})$ were then mixed and $3 \mathrm{~N} \mathrm{HCl}$ was added to this mixture to adjust it to $\mathrm{pH} 3$. This new disinfectant is a colorless and transparent liquid. 
Table 1 Time taken to completely inactivate influenza A viruses following contact with the new disinfectant

\begin{tabular}{|c|c|c|}
\hline \multirow[t]{2}{*}{ Virus strain ${ }^{a}$} & \multicolumn{2}{|c|}{$\begin{array}{l}\text { Time to complete } \\
\text { disinfection (minutes) }\end{array}$} \\
\hline & $1: 9^{b}$ & $1: 99^{\mathrm{b}}$ \\
\hline $\mathrm{H} 1 \mathrm{~N} 110^{8.25} \mathrm{EID}_{50} / 0.2 \mathrm{ml}$ & $>10$ & 10 \\
\hline 10-times diluted & 10 & 10 \\
\hline $\mathrm{H} 3 \mathrm{~N} 210^{8.75} \mathrm{EID}_{50} / 0.2 \mathrm{ml}$ & 10 & 10 \\
\hline 10-times diluted & 10 & 10 \\
\hline H4N6 $10^{8.50} \mathrm{EID}_{50} / 0.2 \mathrm{ml}$ & $>10$ & 10 \\
\hline 10-times diluted & 10 & 10 \\
\hline $\mathrm{H} 5 \mathrm{~N} 310^{8.25} \mathrm{EID}_{50} / 0.2 \mathrm{ml}$ & $>10$ & 2 \\
\hline 10-times diluted & 2 & 2 \\
\hline $\mathrm{H} 6 \mathrm{~N} 210^{7.75} \mathrm{EID}_{50} / 0.2 \mathrm{ml}$ & $>10$ & 10 \\
\hline 10-times diluted & 10 & 10 \\
\hline $\mathrm{H} 7 \mathrm{~N} 710^{8.25} \mathrm{EID}_{50} / 0.2 \mathrm{ml}$ & 10 & 10 \\
\hline 10-times diluted & 10 & 10 \\
\hline
\end{tabular}

$\mathrm{EID}_{50}$, Median egg infectious doses (virus titre)

a H1N1, A/swine/Iowa/15/30; H3N2, A/Aichi/2/68; H4N6, A/duck/ Czech/56; H5N3, A/whistling swan/Shimane/499/83; H6N2, A/duck/ Massachusetts/3740/65; H7N7, A/whistling swan/Shimane/42/80

${ }^{b}$ Ratio of virus to the new disinfectant

This disinfectant was tested on six strains of influenza virus, namely, A/swine/Iowa/15/30 (H1N1), A/Aichi/2/68 (H3N2), A/duck/Czech/56 (H4N6), A/whistling swan/ Shimane/499/83 (H5N3), A/turkey/Massachusetts/3740/65 (H6N2) and A/whistling swan/Shimane/42/80 (H7N7) [5, 6]. Prior to this investigation, these viruses were grown in the allantoic cavity of 10-day-old embryonated SPF hen's eggs for 2 days at $37^{\circ} \mathrm{C}$. The allantoic fluid (virus fluid), which has a very high titre of hemagglutination (HA) activity, was collected and stored at $-80^{\circ} \mathrm{C}$. All virus strains were titrated by inoculating 10-day-old embryonated SPF hen's eggs via the allantoic cavity. Virus titres were expressed as median egg infectious doses $\left(\mathrm{EID}_{50}\right)$ [7]. The titres of all virus strains tested in these experiments were greater than $\log 10^{7.7} \mathrm{EID}_{50} / 0.2 \mathrm{ml}$ (Table 1).

Two strengths of virus fluid were tested: undiluted and diluted tenfold in phosphate buffered saline (pH 7.2). 10and 100-ml samples of both the diluted and undiluted virus fluids were poured into small tubes, made up to $1 \mathrm{ml}$ with the new disinfectant solution, shaken carefully and left at room temperature. After incubations of 2, 10 and $60 \mathrm{~min}$, respectively, the presence of surviving virus was determined by inoculating the virus fluid into the allantoic cavity of 10-day-old SPF hen's eggs.

\section{Experiment 2}

The acute toxicity of this disinfectant to cultured cell lines was investigated. CV-1 monkey kidney cells and Jurkat
Table 2 Cell toxicity of the different disinfectants tested

\begin{tabular}{lccc}
\hline Test reagent & $\begin{array}{l}\text { Final concentration } \\
\text { (\% of the working } \\
\text { solution) }\end{array}$ & \multicolumn{2}{l}{$\begin{array}{l}\text { Percentage inhibition } \\
\text { of cell growth }\end{array}$} \\
\cline { 3 - 4 } & & CV-1 & Jurkat \\
\hline New disinfectant & 10.0 & $60.2 \pm 5.9$ & $48.4 \pm 4.2$ \\
& 1.0 & $28.4 \pm 3.8$ & $22.9 \pm 10.5$ \\
& 0.1 & $18.2 \pm 3.3$ & $4.6 \pm 3.0$ \\
& 0.01 & $13.1 \pm 9.1$ & 0 \\
Chrolhexidine & 0.001 & $5.3 \pm 2.3$ & $1.6 \pm 1.5$ \\
gluconate & 0.0001 & 0 & 0 \\
(positive control) & 10 & 100 & 100 \\
& 1.0 & $99.3 \pm 0.9$ & 100 \\
& 0.1 & $82.0 \pm 1.2$ & $87.0 \pm 14.6$ \\
& 0.01 & $63.2 \pm 5.4$ & $31.0 \pm 18.6$ \\
& 0.001 & $19.9 \pm 7.5$ & $15.6 \pm 6.6$ \\
& & $0.6 \pm 0.8$ & $8.6 \pm 7.6$
\end{tabular}

${ }^{a}$ The new disinfectant is meant to be used undiluted, and thus the working concentration is $100 \%$. At the lowest test dilution, the new disinfectant was added at $10 \%(\mathrm{v} / \mathrm{v})$ strength to the culture media. The recommended working dilution for chrolhexidine gluconate for disinfection of the skin is $0.1-0.5 \%$; therefore, for the highest test concentration, a Hibitane concentrate containing $5 \%(\mathrm{w} / \mathrm{v})$ chrolhexidine gluconate was added at $1 / 50(\mathrm{v} / \mathrm{v})$ to the culture media

${ }^{b}$ Data are presented as the mean \pm standard error of the mean (SEM), calculated from the results of three repeated experiments

human lymphoma cells were seeded at densities of $5 \times 10^{5}$ cells/well and $1.0 \times 10^{5}$ cells/well, respectively, in 24-well tissue culture plates and incubated for $24 \mathrm{~h}$ in tissue culture media. Dulbecco's modified Eagle medium supplemented with $10 \%$ heat-inactivated fetal bovine serum (FBS) was used to culture the CV-1 cells and RPMI-1640 supplemented with $10 \%$ heat-inactivated FBS was used for Jurkat. The new disinfectant and chrolhexidine gluconate as a positive control were added to duplicate wells at the final concentrations indicated in Table 2. The percentages of viable cells were determined by the trypan blue dye exclusion method $48 \mathrm{~h}$ later. Negative control wells were those without the test reagents. The percentages of growth inhibition were calculated by using the following formula:

Percentage growth inhibition $=[($ percentage dead cells in a test well) - (percentage dead cells in a control well)]/ [100 - (percentage dead cells in a control well)].

\section{Results and discussion}

The results of experiment 1 (Table 1) show that all human, a swine and avian influenza $\mathrm{A}$ viruses belonging to the H1N1, H3N2, H4N6, H5N3, H6N6 and H7N7 subtypes lost at least $10^{6} \mathrm{EID}_{50}$ of their infectivity following contact with the new disinfectant for $10 \mathrm{~min}$ at room temperature, 
thereby demonstrating that this disinfectant has a very strong anti-influenza virus activity. We did not use the H5N1 virus in this investigation for the following reason: it is difficult to get a sufficient high titre of $\mathrm{H} 5 \mathrm{~N} 1$ virus since the virulence of this highly pathogenic avian influenza virus is so severe that infected chick embryos died less than $16 \mathrm{~h}$ post inoculation and, therefore, the virus titre in allantoic fluid was generally low. We did succeed in generating a high pathogenicity with this $\mathrm{H} 5 \mathrm{~N} 3$ virus from an avirulent one by passaging it in chicks [5].

In experiment 2 , as shown in Table 2 , the cytotoxicity of the new disinfectant at the working concentration $(100 \%)$ is weaker than that of chrolhexidine gluconate $(0.1-0.5 \%)$.

Based on our results, the new disinfectant has a quick and strong anti-influenza viral activity, and its toxicity is rather weak. All human, swine and avian influenza viruses tested at a titre $>10^{7.7}$ completely lost their infectivity following contact with this new disinfectant for at least $10 \mathrm{~min}$ at room temperature. The acute toxicity of the new disinfectant is much weaker than that of chrolhexidine gluconate. We therefore suggest that this new disinfectant is both a safe and a promising disinfectant and that it can be used in any area where outbreaks of emergent infectious diseases, such as influenza, including that caused by the H1N1 subtype influenza virus, are occurring.

We are currently elucidating the underlying mechanisms of the anti-viral activity of this new disinfectant. We expect to find that the usual anti-bacterial activity of metallic ions is involved and also that the activity of this new disinfectant is stimulated by the existence of another unknown factor.
Our new disinfectant maintains the efficacy stated above for at least 3 years at room temperature (data not shown). It is reasonable to expect that this disinfectant will prove useful in preventing infection from the pandemic H1N1 subtype influenza virus and from other kinds of pathogens.

Acknowledgments We are sincerely grateful to Dr. Jane K. A. Cook, an editor of Avian Pathology for critically reading this manuscript. We are also grateful to Dr. Masaaki Nakai for useful advice.

\section{References}

1. Chen H, Smith GJD, Zhang SY, Quin K, Wang J, Li KS, et al. H5N1 virus outbreak in migratory waterfowl. Nature. 2005;436: 191-2.

2. Mase M, Kim J-H, Lee Y-J, Tsukamoto K, Imada T, Imai K, et al. Genetic comparison of $\mathrm{H} 5 \mathrm{~N} 1$ influenza A viruses isolated from chickens in Japan and Korea. Microbiol Immunol. 2005;49:871-4.

3. Muramoto Y, Mai Le TH, Phuong LS, Nguyen T, Nguyen TH, Sakai-Tagawa Y, et al. Molecular characterization of the hemagglutinin and neuraminidase genes of $\mathrm{H} 5 \mathrm{~N} 1$ influenza A viruses isolated from poultry in Vietnam from 2004 to 2005. J Vet Med Sci. 2006;68:527-31.

4. Webster RG, Bean WJ, Gorman OT, Chambers TM, Kawaoka Y. Evolution and ecology of influenza A viruses. Microbiol Rev. 1992;56:152-79.

5. Ito T, Goto H, Yamamoto E, Tanaka H, Takeuchi M, Kuwayama $\mathrm{M}$, et al. Generation of a highly pathogenic avian influenza A virus from an avirulent field isolate by passing in chickens. J Virol. 2001;75:4439-43.

6. Otsuki K, Yamazaki K, Kawaoka Y, Tsubokura M. Intracerebral pathogenicity for chickens of avian influenza viruses isolated from free-living waterfowls in Japan. Vet Microbiol. 1988;18:357-62.

7. Reed LJ, Muench H. A simple method of estimating fifty per cent endpoints. Am J Hyg. 1938;27:493-7. 